\title{
Filamentous Bacteria in Sediments of Lakes of Differing Degrees of Enrichment
}

\author{
By MIRNA J. L. GODINHO-ORLANDI† AND J. GWYNFRYN JONES* \\ Freshwater Biological Association, Windermere Laboratory, The Ferry House, Ambleside, \\ Cumbria LA22 OLP
}

(Received 26 June 1980; revised 3 September 1980)

\begin{abstract}
Estimates of sediment populations of filamentous bacteria were made by a variety of direct count procedures including the use of acridine orange and fluorescein diacetate, and by a viable (most probable number) technique. The counts with acridine orange showed an upward trend with increasing degree of enrichment of the lakes, particularly at the eutrophic end of the spectrum. The distribution pattern obtained with fluorescein diacetate was different, with an apparent upward trend in the intermediate lakes. The profundal and littoral zones of three lakes were examined both at the onset of thermal stratification and in late summer, when they were stratified and the hypolimnion of the eutrophic lake was anoxic. Consistently higher counts were obtained in the profundal zone, the difference being more marked in early summer. There were distinct differences between the lakes in the depth distribution of the filamentous bacteria in the sediments.
\end{abstract}

\section{INTRODUCTION}

Early aquatic microbiologists devoted much of their time to the study of bacteria in the water column. Since the work of Henrici \& McCoy (1938) and ZoBell (1946) there has been a steadily growing literature on sediment microbiology in spite of some of the difficulties encountered by the earlier workers (e.g. the differentiation of non-living particles and bacteria by light microscopy). The problems of studying bacterial populations in the sediments are still greater than in the water column, largely due to the presence of steeper chemical and physical gradients, the masking effect of detrital particles in direct counts, and the occurrence of large numbers of spreading colonies if standard spread plate techniques are used. These difficulties may have contributed to the change in emphasis to research aimed at measurements of processes in sediments, particularly those of the geochemical cycles. Reasonably reliable estimates have been obtained, for example, of rates of methanogenesis, sulphate reduction and denitrification (Rudd \& Hamilton, 1978; Jørgensen, 1978; Sørensen, 1978) as has a better understanding of the interactions of the processes (Nedwell \& Abram, 1979; Winfrey \& Zeikus, 1979). This examination of processes has reawakened an interest in the organisms which may be performing these functions, and brought a realization that perhaps the techniques used originally would not necessarily isolate all the organisms concerned, particularly those involved in tightly coupled consortia (Bryant et al., 1967). In this re-examination of bacterial groups, those responsible for general heterotrophic processes have to some degree been ignored, partly because of the absence of a reliable measure of heterotrophic production. In particular, the role of filamentous bacteria requires further study. Much of our recent knowledge on their identification has been derived from the study of man-made systems, e.g. sewage sludge (Farquhar \& Boyle, 1971; van Veen, 1973;

† Present address: Universidade Federal de São Carlos, Departamento de Ciências Biológicas, 13560 São Carlos SP, Brazil. 
Eikelboom, 1975), yet early workers (Pringsheim, 1951; Skuja, 1956) consistently isolated these forms from freshwater sediments.

This paper is concerned with filamentous bacteria, defined for our purpose as any thread-like form, segmented or not, $10 \mu \mathrm{m}$ or more in length. We had observed that, with a few exceptions such as Leptothrix spp. (Jones, 1975), filamentous bacteria were almost exclusively confined to the sediment and therefore may play some intrinsic role at solid-liquid interfaces. Before detailed studies could start, some understanding of the population ecology of these organisms was required, and this paper examines their distribution in a series of Cumbrian lakes. The sediments of these lakes have already been shown to differ in their microbiological characteristics, with greater microbial activity, biomass and numbers being found in the lakes at the eutrophic end of the spectrum (Jones et al., 1979).

\section{METHODS}

Sampling. The 17 lakes investigated, all in the English Lake District, are listed in Table 1, ranked according to their trophic status; their positions are given in Ramsbottom (1979). Sediment samples were taken with a Jenkin surface mud corer at a fixed station near the deepest point in each lake (profundal samples) and at the nearest point to the shore with soft sediment (littoral samples).

Direct counts on membrane filters. The top $1 \mathrm{~cm}$ layer of the sediment was removed using a screw extruder (Jones, 1976) of known pitch $(2 \mathrm{~mm})$. A sub-sample was mixed with an equal volume of membrane-filtered $(0.22 \mu \mathrm{m}$ pore size) lake water and homogenized for $1 \mathrm{~min}$ with an Ultra Turrax homogenizer (Janke \& Kunkel IKA Products) set at 20000 rev. min $^{-1}$. Preliminary trials had shown that this procedure yielded the highest count of bacteria with reasonable particle dispersion. Membrane-filtered lake water $(3 \mathrm{ml})$ was added to the homogenate and the sample was then diluted with membrane-filtered lake water to a final dilution of $10^{-3}$. For counts using acridine orange $(\mathrm{AO})$ the Jones \& Simon $(1975 \mathrm{a})$ procedure was used. AO (10 $\mathrm{mg} \mathrm{l}^{-1}$ final concentration) was added to the diluted sample which was allowed to stand for $5 \mathrm{~min}$ and then filtered through a $25 \mathrm{~mm}$ black membrane filter (Sartorius; $\mathbf{0 . 2 2} \mu \mathrm{m}$ pore size). The microscope used was a Leitz Orthoplan equipped with a Ploem illuminator for epifluorescence studies. A $200 \mathrm{~W}$ mercury burner (HBO 200) served as a light source and the following filter combination was used (Leitz notations provided): a Calflex B1/K2 interference heat filter and

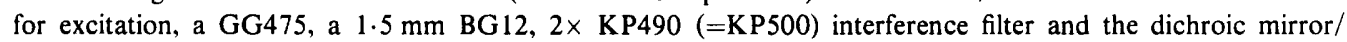
suppression filter combination TK510/K515. The image was viewed through a $\mathrm{K} 530 \mathrm{~mm}$ barrier at $\times 1250$ magnification. The count with AO may be considered as an estimate of the total bacterial population but there was no evidence that all the cells counted were viable (Jones \& Simon. 1975a).

For counts using fluorescein diacetate (FDA) the method was based on that described by Paton \& Jones (1975). The pretreatment of the sample was as described above except that the final dilution was prepared with filtered phosphate-buffered saline $\mathrm{pH} 7.5$ with a final $\mathrm{NaCl}$ concentration of $8 \mathrm{~g} \mathrm{l}^{-1}$. Two $\mathrm{ml}$ of the diluted sample was dispensed on to the membrane, $0.2 \mathrm{ml}$ of a freshly prepared solution of FDA (Koch-Light; $100 \mathrm{mg} \mathrm{l}^{-1}$ in phosphate-buffered saline) was added, and the sample was allowed to stand for $30 \mathrm{~s}$. A further $4 \mathrm{ml}$ buffer was then added and the mixture was filtered as above. The microscopic procedure was that used for AO counts except that the exciter filter combination consisted of a Calflex B1/K2 interference heat filter and an S470 interference filter. The count obtained with FDA may be considered as a direct estimate of potentially viable cells since the presence of fluorescence indicates metabolic activity often associated with an intact membrane structure.

\section{Table 1. The lakes examined, ranked according to trophic status, and their maximum depths}

The lakes were ranked from oligotrophic (low numbers) to eutrophic (high numbers) by the criteria used by Jones et al. (1979). Numbers in parentheses indicate the depth of the littoral sites sampled.

\begin{tabular}{clcclc} 
Rank & \multicolumn{1}{c}{ Lake } & Depth $(\mathrm{m})$ & Rank & \multicolumn{1}{c}{ Lake } & Depth $(\mathrm{m})$ \\
1 & Wastwater & $76(1)$ & 10 & Derwentwater & 22 \\
2 & Ennerdale & 42 & 11 & Bassenthwaite & 19 \\
3 & Buttermere & 29 & 12 & Windermere, S. & $42(6)$ \\
4 & Crummock Water & 44 & 13 & Loweswater & 16 \\
5 & Haweswater & 57 & 14 & Rydal Water & $18 \cdot 5$ \\
6 & Coniston & 56 & 15 & Grasmere & $21 \cdot 5$ \\
7 & Thirlmere & 46 & 16 & Esthwaite Water & $15 \cdot 5$ \\
8 & Windermere, N. & 64 & 17 & Blelham Tarn & $14 \cdot 5(2)$ \\
9 & Ullswater & 62.5 & & &
\end{tabular}


Direct counts on marked slides. The method was based on that of Trolldenier (1973). To $10 \mathrm{ml}$ of a $10^{-1}$ dilution of sediment, $1 \mathrm{ml}$ of a freshly prepared $1 \%(\mathrm{w} / \mathrm{v})$ agar solution was added. The suspension was vigorously shaken by hand for $30 \mathrm{~s}$ and then $10 \mu \mathrm{l}$ was transferred to a glass slide on which two concentric circles. $7.72 \mathrm{~mm}$ and $11.3 \mathrm{~mm}$ in diameter, had been engraved. The suspension was evenly distributed within the larger circular area $\left(1 \mathrm{~cm}^{2}\right)$ and allowed to dry at room temperature. The smear was then covered with a solution of AO $\left(20 \mathrm{mg} \mathrm{I}^{-1}\right)$ for $10 \mathrm{~min}$, washed with distilled water and covered with a coverslip. Fifty fields were counted, while the preparation was still wet, using the same filter combination as for FDA counts. The counts were made immediately within the inner circle where the agar film was usually of average thickness (Trolldenier, 1973).

Direct counts in wet mounts. The method used was based on that described by Edmondson (1974). A 10-1 dilution of sediment was vigorously shaken by hand for $30 \mathrm{~s}$. AO (10 $\mathrm{mg} \mathrm{l}^{-1}$ final concentration $)$ was added and the sample was allowed to stand for $5 \mathrm{~min}$. It was then reshaken, and $40 \mu \mathrm{l}$ was delivered on to a glass slide. covered with a coverslip and examined at $\times 500$ magnification. The fluorescence filter combination was the same as that used for FDA counts.

Most probable number $(M P N)$ counts. Heterotrophic medium $\left(\mathrm{g} \mathrm{l}^{-1}\right.$. in distilled water: $\mathrm{K}_{2} \mathrm{HPO}_{4}, 0 \cdot 2$; $\mathrm{MgSO}_{4} .7 \mathrm{H}_{2} \mathrm{O}, 0.05$; glucose, 0.01 ; peptone, 0.01 ; yeast extract, $0.01 ; \mathrm{FeCl}_{3}, 4$ drops of a $0.01 \%$ solution) was dispensed into the compartments of Replidishes (Sterilin). Serial dilutions were then made with sterile $1 \mathrm{ml}$ piston pipette tips which were also used to mix the inoculum and medium. Six fourfold dilutions were prepared with eight replicates at each dilution. To each compartment a piece of sterile cellophane (British Cellophane Ltd; PT 400) was added to stimulate growth of the filaments, many of which either grew on or were attracted to surfaces. The dishes were sealed with adhesive tape and incubated at $15^{\circ} \mathrm{C}$ for $10 \mathrm{~d}$. The cellophane was then removed and examined under phase-contrast illumination at $\times 500$ magnification. Positive scores were given to compartments in which filamentous bacteria were found growing on the cellophane. The MPN was calculated from the table of Harris \& Sommers (1968).

Counts of filamentous bacteria on coated slides. Glass slides ignited at $500^{\circ} \mathrm{C}$ for $2 \mathrm{~h}$ were coated with molten $2 \%$ agar. The slides were dried in a dust-free environment and inserted vertically into the sediment cores leaving about $2 \mathrm{~cm}$ above the sediment-water interface. The cores were incubated at $8^{\circ} \mathrm{C}$ for 7 or $14 \mathrm{~d}$. The slides were then examined under phase-contrast illumination at a magnification of $\times 400$. For some counts. gelatin $(0.5 \%)$ or Ullich's adhesive (Brock \& Brock. 1968) was used instead of agar for coating the slides.

Analysis of data. One of the aims of this investigation was to determine whether numbers of filamentous bacteria correlated with the trophic status of the lake. The lakes were arranged in order of increasing degree of enrichment (see Table 1), and the correlation between bacterial numbers and the lake trophic status. expressed as its rank on an ordinal scale, could be calculated (Jones, 1973). All other differences between groups of lakes were tested by non-parametric analysis of variance. Bacterial population estimates obtained using membrane-filter techniques were based on total counts of 400 bacteria in each sample: thus, confidence limits on individual counts were approximately $\pm 10 \%$ of the mean. All other direct count estimates were the arithmetic means of 50 counts on each of four sampling occasions.

\section{RESULTS AND DISCUSSION}

Several genera of filamentous bacteria have been isolated from and observed in freshwater sediment by Pringsheim (1951), Maier \& Murray (1965), Lewin \& Lounsbery (1969), Strohl \& Larkin (1978) and others. For the purposes of this investigation we defined filaments as being longer than $10 \mu \mathrm{m}$; amongst the genera encountered in the lakes studied, Leptothrix, Beggiatoa, Vitreoscilla, Flexibacter and Pseudanabaena were the most common.

The lakes investigated (Table 1) ranged from deep oligotrophic lakes (numbers 1 to 4) to shallow nutrient-rich water bodies as exemplified by Esthwaite Water and Blelham Tarn. A preliminary survey, based on membrane counts and an MPN technique, was undertaken to provide background information on the sediments of the lakes, since the filamentous bacteria of the benthos had not been studied in detail before. This survey was confined to the profundal zone of the lakes. The numbers of filamentous bacteria estimated by direct counts on membrane filters are presented in Fig. $1(a, b)$. The counts with AO showed a significant $(P<$ 0.01 ) upward trend with increasing degree of enrichment of the lakes particularly at the eutrophic end of the spectrum. The ranges observed were also wider in the nutrient-rich lakes than in the nutrient-poor ones. The counts ranged from $0.03 \times 10^{8}$ filaments $(\mathrm{g} \text { dry wt })^{-1}$ in Bassenthwaite to $12 \times 10^{8}$ filaments (g dry wt) $)^{-1}$ in Blelham Tarn. The counts with FDA ranged from $0.14 \times 10^{8}$ filaments ( $\mathrm{g}$ dry wt) ${ }^{-1}$ in Buttermere to $1.95 \times 10^{8}$ filaments ( $\mathrm{g}$ dry $w t)^{-1}$ in Esthwaite Water. The distribution pattern of bacteria stained with FDA was rather 


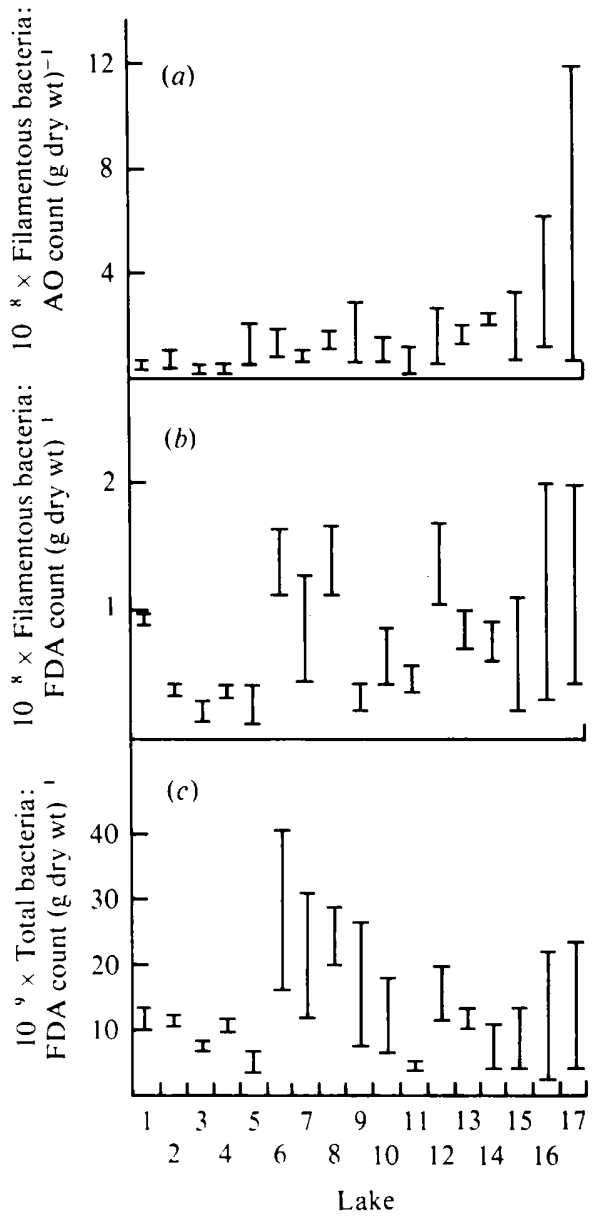

Fig. 1
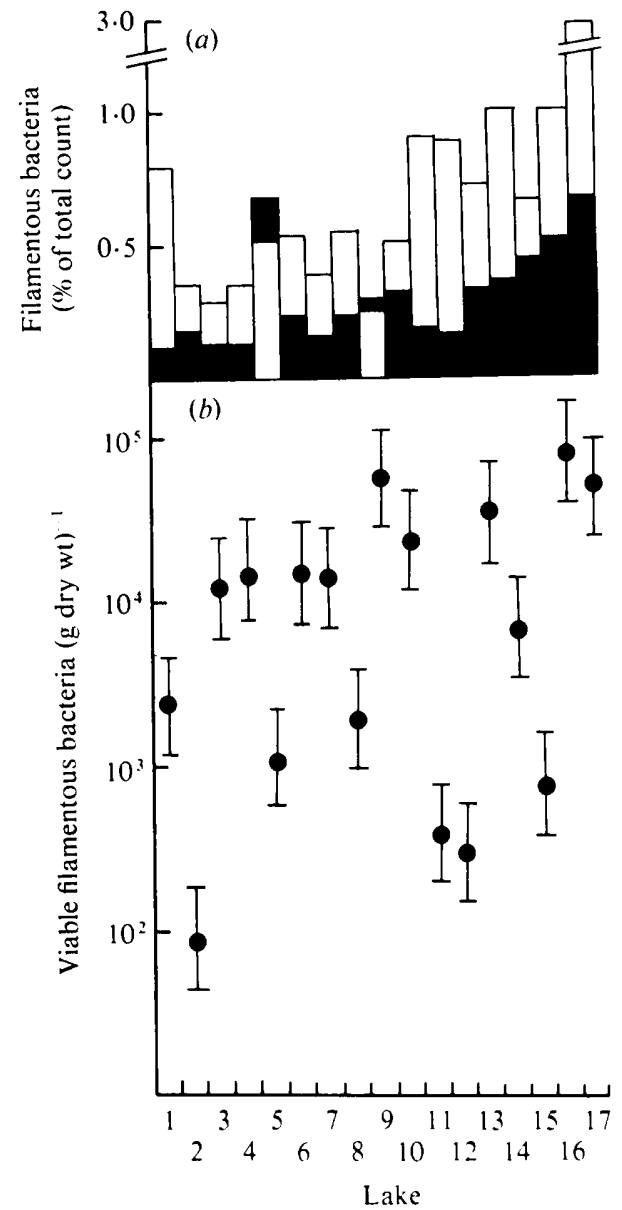

Fig. 2

Fig. 1. Direct counts of bacteria in the surface sediments of 17 lakes arranged in order of increasing degree of nutrient enrichment (lake numbering as in Table 1). Samples were counted on black membrane filters by epifluorescence microscopy. The bars indicate the range of values obtained during summer stratification. each sample being counted to a precision of $\pm 10 \%$ of the mean. $(a)$ Counts of filamentous bacteria stained with acridine orange. (b) Counts of filamentous bacteria stained with fluorescein diacetate. (c) Counts of total bacteria stained with fluorescein diacetate.

Fig. 2. (a) Direct counts of filamentous bacteria stained with acridine orange ( $\square$ ) and fluorescein diacetate $(\square)$, expressed as a percentage of the total bacterial counts (stained with the same fluorochromes) in the surface sediments of 17 lakes arranged in order of increasing nutrient enrichment. as in Fig. 1. Samples were counted on black membrane filters by epifluorescence microscopy.

(b) Viable (MPN) counts of filamentous bacteria using liquid heterotrophic medium plus pieces of cellophane. Incubation was at $15^{\circ} \mathrm{C}$ for $10 \mathrm{~d}$. Samples were taken from the surface sediment of the 17 lakes. The bars indicate $95 \%$ confidence limits.

different and the correlation with lake trophic status was not significant $(P=0.08)$. This fluorigenic substrate has been used successfully to count viable eukaryotic cells (Paton \& Jones, 1975) but results with the prokaryotes have been variable (Jones \& Simon. 1975a). Satisfactory fluorescence has, however, been obtained at this laboratory with filamentous cyanobacteria and therefore the technique was adopted here. There was an apparent upward trend in the FDA counts in the intermediate lakes, this being more marked in the counts of the total population of bacteria. (Fig. $1 \mathrm{c}$ ). The counts obtained from lakes 6 to 10 were significantly higher $(P=0.05)$ than those from the oligotrophic and eutrophic lakes grouped 
Table 2. Comparison of the variability between and within sediment cores in bacterial counts on membrane filters using acridine orange $(A O)$ and fluorescein diacetate $(F D A)$ stains

\begin{tabular}{|c|c|c|c|c|c|c|c|c|}
\hline & \multicolumn{4}{|c|}{ Total bacteria/graticule area } & \multicolumn{4}{|c|}{ Filamentous bacteria/microscopic field } \\
\hline & \multicolumn{2}{|c|}{$\mathrm{AO}$} & \multicolumn{2}{|c|}{ FDA } & \multicolumn{2}{|c|}{$\mathrm{AO}$} & \multicolumn{2}{|c|}{ FDA } \\
\hline & Between & Within & Between & Within & Between & Within & Between & Within \\
\hline Mean & $5 \cdot 73$ & 8.96 & $1 \cdot 54$ & $7 \cdot 81$ & $2 \cdot 37$ & $2 \cdot 27$ & $0 \cdot 78$ & 0.73 \\
\hline Variance & $1 \cdot 15$ & 0.28 & 0.58 & $0 \cdot 14$ & 0.27 & 0.17 & 0.04 & 0.04 \\
\hline No. of samples & 5 & 5 & 5 & 5 & 5 & 5 & 5 & 5 \\
\hline Coefficient of variation (\%) & 18.67 & $5 \cdot 92$ & $49 \cdot 35$ & $4 \cdot 74$ & $21 \cdot 94$ & $18 \cdot 06$ & $25 \cdot 64$ & 28.77 \\
\hline $\begin{array}{l}\text { Sampling units required:* } \\
(a) \\
(b)\end{array}$ & $\begin{array}{r}4 \\
10\end{array}$ & $\begin{array}{l}1 \\
1\end{array}$ & $\begin{array}{l}24 \\
67\end{array}$ & $\begin{array}{l}1 \\
1\end{array}$ & $\begin{array}{r}5 \\
13\end{array}$ & $\begin{array}{l}3 \\
9\end{array}$ & $\begin{array}{r}7 \\
19\end{array}$ & $\begin{array}{r}8 \\
22\end{array}$ \\
\hline
\end{tabular}

* (a) To obtain a standard error of $10 \%$ of the mean: $(b)$ to obtain a $95 \%$ confidence limit of $10 \%$ of the mean: values are rounded to the nearest whole number.

on either side. The result was obtained in spite of the inherent variability of the data (Table 2). Two other factors also indicated that the higher counts obtained in the intermediate lakes represented a real trend. In the first place, between-core variability with FDA counts of filaments was lower than similar counts of the total population and, secondly, the trend was observed in more than one lake and was not an isolated incident. Since cells which fluoresced in the presence of FDA were considered to be viable, possible explanations are that either there was a real increase in viability of filaments in the intermediate lakes, or that viability was significantly lower at the oligotrophic extreme and that FDA fluorescence was quenched to a greater extent than that of $\mathrm{AO}$ by reducing substances in the sediment of the more eutrophic lakes. When filamentous bacteria were expressed as a percentage of the total population (Fig. $2 a$ ) the counts obtained with FDA gave higher values than those obtained with $\mathrm{AO}$ for all lakes except Haweswater and Ullswater; the FDA counts also showed greater variability between lakes than the counts obtained using AO. In spite of this variability the increasing importance of filamentous bacteria as a proportion of the total population was significantly correlated $(P<0.01)$ with lake trophic status. Although the filamentous bacteria represented a numerically small proportion (usually $<1 \%$ ) of the total population, their quantitative importance has been underestimated since they were always counted as whole filaments and not as cells within the filaments. In addition, their numbers bear no relation to their biomass and activity. Jørgensen (1977) has shown that relatively low numbers of Beggiatoa were much more important in terms of biomass and made a major contribution to carbon turnover in offshore sediments. In our samples, in spite of their low numbers, an average biomass of $15 \times 10^{10} \mu^{3} \mathrm{~g}^{-1}$ was obtained for the filaments compared with $7 \cdot 1 \times$ $10^{10} \mu \mathrm{m}^{3} \mathrm{~g}^{-1}$ for the unicellular bacteria. These values are only approximations based on cell counts and average volumes but they serve to illustrate the potential importance of the filamentous bacteria.

Figure $2(b)$ shows the distribution of viable (MPN) counts of filamentous bacteria in the 17 lakes. The results, presented on a logarithmic scale, showed a slight upward trend with increasing degree of enrichment of the lakes, but this was not significant $(P=0.09)$ and overall variability was very high. A variety of forms were observed on the cellophane strips in the MPN chambers but this method was particularly selective for members of the genus Flexibacter.

The preliminary survey of the sediments of the 17 lakes led to the selection of three lakes, representing the oligotrophic. mesotrophic and eutrophic states, for further study. The number of bacteria present and the extent to which anoxic conditions developed in the hypolimnion were the two main factors considered in choosing the lakes, which were 
Table 3. Values obtained when different techniques were used for enumerating filamentous bacteria in surface sediments

These values (counts $\mathrm{ml}^{-1}$ ) are intended merely as a guide to the order of magnitude of the count that might be expected using the techniques shown. The variability of the data was of the order of that shown in columns 5 and 6 of Table 2 .

Lake

Wastwater

Windermere, $\mathbf{S}$.

Blelham Tarn

$\begin{array}{cccccc}\begin{array}{c}\text { AO counts } \\ \text { on membranes }\end{array} & \begin{array}{c}\text { Marked } \\ \text { slides }\end{array} & \begin{array}{c}\text { Wet mounts } \\ \text { (AO) }\end{array} & \begin{array}{c}\text { Wet mounts } \\ \text { (phase-contrast) }\end{array} & \begin{array}{c}\text { Agar-coated } \\ \text { slides }\end{array} & \text { MPN } \\ 10^{7} & 10^{6} & 10^{6} & 10^{4} & 10^{3} & 10^{3} \\ 10^{7} & 10^{6} & 10^{6} & 10^{4} & 10^{6} & 10^{2} \\ 10^{8} & 10^{7} & 10^{5} & 10^{5} & 10^{5} & 10^{4}\end{array}$

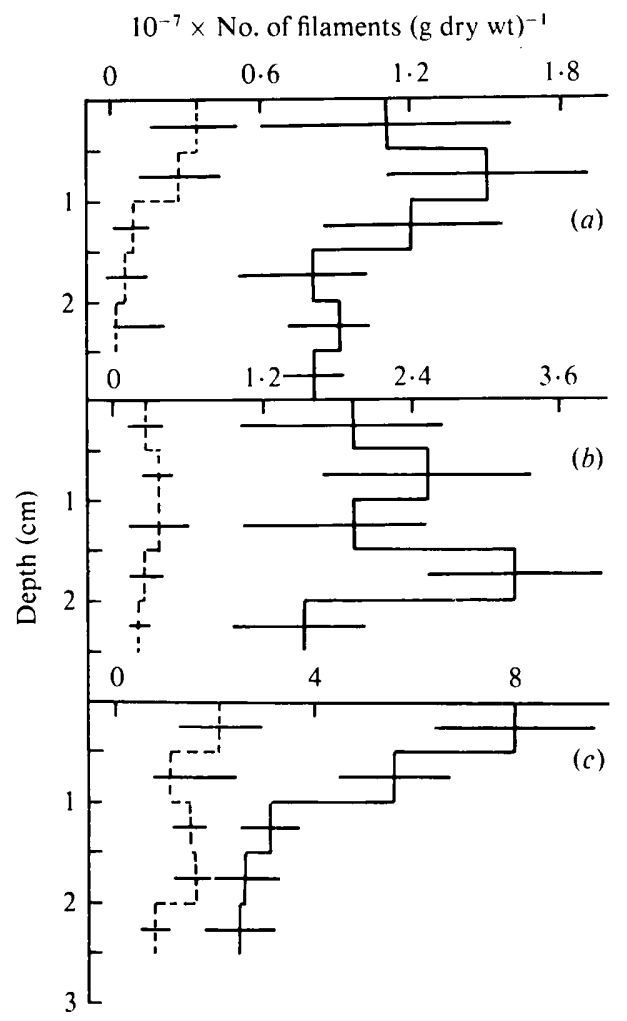

Fig. 3. Vertical distribution of filamentous bacteria before the onset of stable thermal stratification in profundal ( - ) and littoral (-- - ) sediments of Wastwater $(a)$, Windermere, South Basin $(b)$ and Blelham Tarn $(c)$. Samples were counted by the marked slide technique. The bars indicate $95 \%$ confidence limits.

Wastwater (deep, oligotrophic), Windermere, South Basin (deep, mesotrophic) and Blelham Tarn (shallow, eutrophic). Sampling of both the profundal and littoral zones was carried out to provide some information on the variability in the populations of filamentous bacteria within the lakes. Results from the preliminary survey had shown that although it was possible to obtain relative estimates of the populations of filamentous bacteria, the handling procedures, particularly homogenization, may have been destructive. Therefore an investigation of counting procedures which would not cause fragmentation of the filaments was undertaken before a detailed examination of the sediment started. Vigorous shaking by hand did not break the filaments, but organisms and sediment particles remained clumped to such a degree that not all the bacteria could be seen under the conditions used for epifluorescence on 


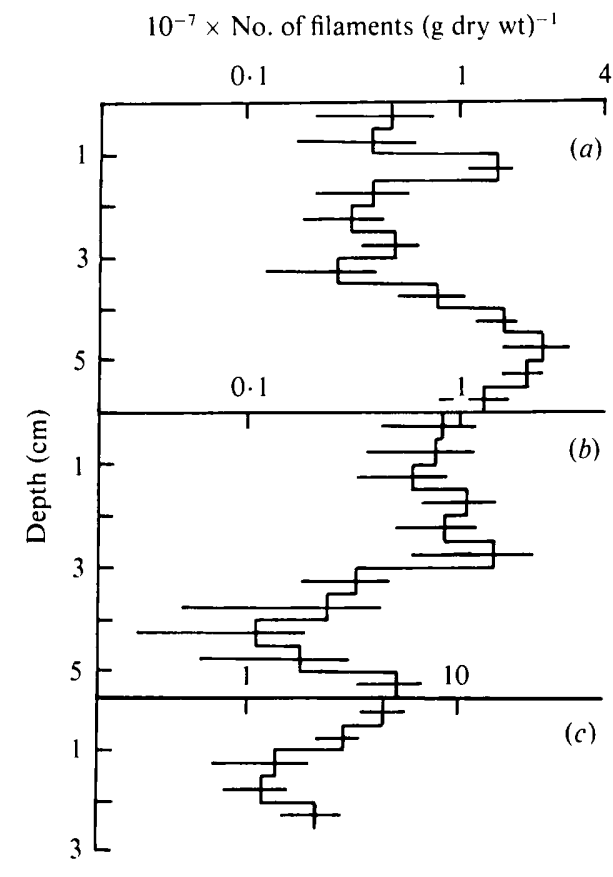

Fig. 4

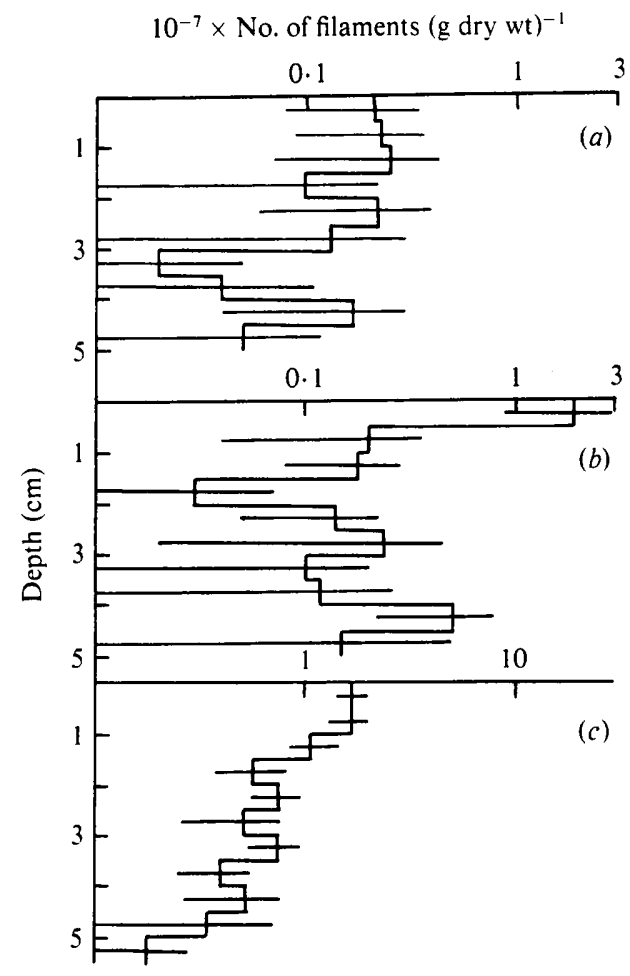

Fig. 5

Fig. 4. Vertical distribution of filamentous bacteria in late summer after prolonged thermal stratification in profundal sediments of Wastwater $(a)$, Windermere, South Basin $(b)$ and Blelham Tarn $(c)$. Other details as for Fig. 3.

Fig. 5. Vertical distribution of filamentous bacteria in late summer after prolonged thermal stratification in littoral sediments of Wastwater $(a)$, Windermere, South Basin $(b)$ and Blelham Tarn $(c)$. Other details as for Fig. 3.

black membrane filters. Two other techniques involving the use of AO, viz. marked slides and wet mounts, were therefore developed. These allowed more intensive staining, and therefore increased visibility, of the filaments. Their main disadvantage was that material remained clumped and variability was greater; therefore the number of fields counted was never less than 50. The marked slides proved to be the more satisfactory, resulting in a clear preparation which was easier to count. The approximate values obtained by the methods used in this study are summarized in Table 3. The various methods produced counts which differed by orders of magnitude and therefore only approximate values are shown. The variability of each method was similar to that shown in Table 2, columns 5 and 6 . Of the three direct count procedures used, the highest counts were obtained on black membranes after staining with AO (presumably because of fragmentation during the harsher homogenization process), and the lowest with wet mounts. The fact that the AO counts in wet mounts were lower that those on black membranes may have been due to the masking effect of large sediment particles. In addition, sediment reducing substances (e.g. $\mathrm{Fe}^{2+}$ ) were more likely to be present in the wet mounts, particularly in samples from the eutrophic Blelham Tarn, and these are known to quench fluorescence (Jones \& Simon, 1975b). Additional evidence for this latter suggestion was obtained when some filaments observed under phase-contrast illumination did not fluoresce. Identical filaments in well-aerated sediments fluoresced readily. Generally, however, the use of epifluorescence allowed us to see many filaments within sediment particles which 

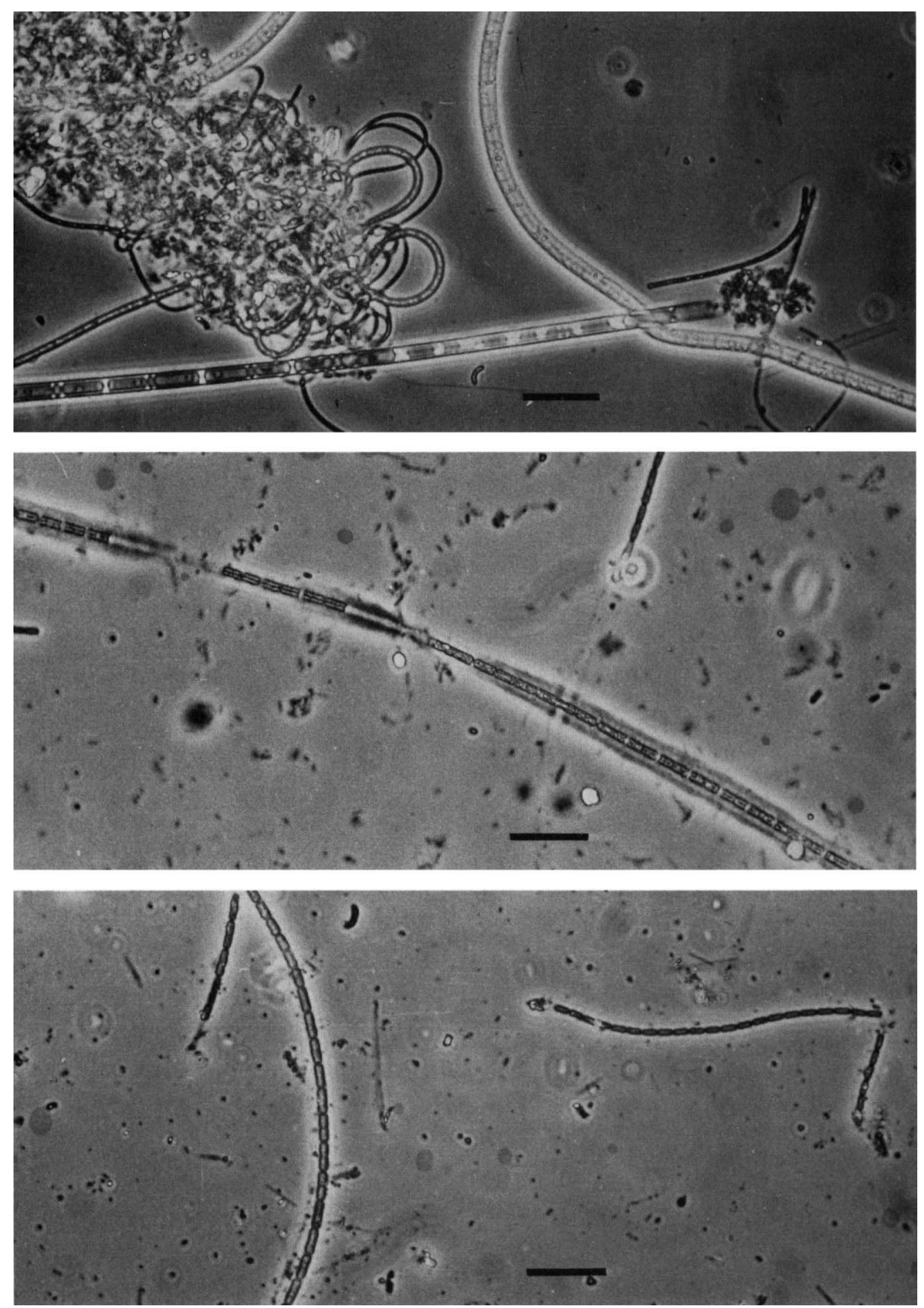

Fig. 6. Examples of filamentous bacteria observed on agar-coated slides incubated in sediment cores. The bar markers represent $20 \mu \mathrm{m}$. 
could not be resolved by phase-contrast microscopy; therefore the counts obtained in wet mounts were higher when the fluorochrome was used.

The vertical distribution of filamentous bacteria in the sediment of the three lakes was examined. The samples for counting were taken to the depth at which the $E_{\mathrm{h}}$ became constant (Jones et al., 1979). The vertical distribution of filamentous bacteria at the onset of thermal stratification, and in late summer, when the hypolimnion of Blelham Tarn had become deoxygenated, are shown in Figs 3, 4 and 5. The counts were consistently higher in the profundal samples than in those from the littoral zone, the difference being particularly marked at the beginning of the summer. The population estimates for Blelham Tarn were significantly higher than those obtained for the other two lakes. The filamentous bacteria in Blelham Tarn were found in largest numbers in the top $1 \mathrm{~cm}$ of sediment and numbers decreased with depth in both profundal and littoral sediments. This pattern was not observed in Windermere, South Basin and Wastwater where sub-surface peaks of numbers occurred.

Although the direct count estimates of the bacteria in the littoral and profundal sediments were consistent with previously published data (Jones, 1980), the fact that the cells stained positively with AO or FDA did not provide conclusive proof of their viability (i.e. the ability to grow and divide). We decided that a technique which would encourage growth after colonization of a surface, while not providing a quantitative estimate of numbers, would provide valuable additional information on the distribution of viable filaments. Accordingly, microscope slides coated with agar, gelatin or Ullrich's adhesive were inserted vertically into the sediment cores and incubated for different periods of time. The most satisfactory results, i.e. those which yielded a high count with greatest variety of filamentous types, were obtained with agar-coated slides incubated for $7 \mathrm{~d}$. When corrected to a volume basis, the counts were generally higher than those obtained by the MPN procedure and comparable with counts of wet mounts by phase-contrast microscopy (Table 3). Examples of some of the filamentous bacteria obtained on such slides are illustrated in Fig. 6 .

This preliminary survey has provided some basic information on the sediment sites where filamentous bacteria may be found. Techniques have been developed which have allowed us to observe the distribution of the total population of filamentous bacteria, but further information is required on the distribution of individual taxonomic groups in the sediment environment.

We are grateful to all who gave access and permission to sample the lakes, to T. I. Furnass who printed the photographs and to Miss E. M. Evans who typed the script. M.J.L.G.-O. gratefully acknowledges the receipt of a scholarship from CAPES (Co-ordination of the Upgrading of University Graduate Level Personnel) Brazil.

\section{REFERENCES}

Brock, M. L. \& Brock, T. D. (1968). The application of micro-autoradiographic techniques to ecological studies. Mitteilungen der Internationalen Vereinigung für theoretische und angewandte Limnologie 15. $1-29$.

Bryant, M. P., Wolin, E. A.. Wolin, M. J. \& Wolfe, R. S. (1967). Methanobacillus omelianskii: a symbiotic association of two species of bacteria. Archiv für Mikrobiologie 59, 20-31.

EDMONDSON, W. T. (1974). A simplified method for counting phytoplankton. In A Manual on Methods for Measuring Primary Production in Aquatic Environments, pp. 14-16. Edited by R. A. Vollenweider. Oxford: Blackwell Scientific Publications.

Eikelboom. D. H. (1975). Filamentous organisms observed in activated sludge. Water Research 9. 365-388.

FARquhar, G. J. \& Boyle. W. C. (1971). Occurrence of filamentous microorganisms in activated sludge.
Journal of the Water Pollution Control Federation 43, 779-798.

HARris, R. F. \& Sommers, L. E. (1968). Plate-dilution frequency technique for assay of microbial ecology. Applied Microbiology 16, 330-334.

Henrici, A. T. \& McCoy, E. (1938). The distribution of heterotrophic bacteria in the bottom deposits of some lakes. Transactions of the Wisconsin Academy of Sciences, Arts and Letters 31, 323-361.

JoNES, J. G. (1973). Use of non-parametric tests for the analysis of data obtained from preliminary surveys: a review. Journal of Applied Bacteriology 36, 197-210.

JoNes, J. G. (1975). Some observations on the occurrence of the iron bacterium Leptothrix ochracea in fresh water, including reference to large experimental enclosures. Journal of Applied Bacteriologv 39, 63-72.

JONES, J. G. (1976). The microbiology and decomposition of seston in open water and experi- 
mental enclosures in a productive lake. Journal of Ecologv 64, 241-278.

JONES, J. G. (1980). Some differences in the microbiology of profundal and littoral lake sediments. Journal of General Microbiologv 117, 285-292.

JoNES, J. G. \& Simon, B. M. (1975a). An investigation of errors in direct counts of aquatic bacteria by epifluorescence microscopy, with reference to a new method for dyeing membrane filters. Journal of Applied Bacteriology 39, 317-329.

JoNES, J. G. \& Simon, B. M. (1975 b). Some observations on the fluorometric determination of glucose in freshwater. Limnology and Oceanography 20, 882-887.

Jones, J. G., Orlandi, M. J. L. G. \& Simon, B. M. (1979). A microbiological study of sediments from the Cumbrian lakes. Journal of General Microbiology 115, 37-48.

JøRGENSEN, B. B. (1977). Distribution of colorless sulfur bacteria (Beggiatoa spp.) in a coastal marine sediment. Marine Biologv 41, 19-28.

JøRGENSEN, B. B. (1978). A comparison of methods for the quantification of bacterial sulfate reduction in coastal marine sediments. I. Measurement with radiotracer techniques. Geomicrobiologv Journal 1, 11-27.

LEWIN, R. A. \& Lounsbery, D. M. (1969). Isolation, cultivation and characterization of flexibacteria. Journal of General Microbiologv 58, 145-170.

Maier, S. \& Murray, R. G. E. (1965). The fine structure of Thioploca ingrica and a comparison with Beggiatoa. Canadian Journal of Microbiology 11. 645-655.

Nedwell, D. B. \& Abram, J. W. (1979). Relative influence of temperature and electron acceptor concentrations on bacterial sulfate reduction in saltmarsh sediment. Microbial Ecology 5, 67-72.

Paton, A. M. \& Jones, S. M. (1975). The observation and enumeration of micro-organisms in fluids using membrane filtration and incident fluorescence microscopy. Journal of Applied Bacteriology 38. 199-200.

Pringsheim, E. G. (1951). The Vitreoscillaceae: a family of colourless, gliding, filamentous organisms. Journal of General Microbiologv 5, 124-149.

Ramsiotrom, A. E. (1976). Depth charts of the Cumbrian lakes. Freshwater Biological Association Scientific Publication No. 33.

RudD, J. W. M. \& Hamilton, R. D. (1978). Methane cycling in a eutrophic shield lake and its effects on whole lake metabolism. Limnologv and Oceanography 23, 337-348.

Skuja, H. (1956). Taxonomische und biologische Studien über das Phytoplankton schwedischer Binnengewässer. Nova acta Regiae Societatis Scientiarum upsaliensis Ser. 4, 16, 1-404.

SøRENSEN, J. (1978). Denitrification rates in a marine sediment as measured by the acetylene inhibition technique. Applied and Environmental Microbiology 36, 139-143.

STrohl, W. R. \& LARKIN, J. M. (1978). Enumeration, isolation, and characterization of Beggiatoa from freshwater sediments. Applied and Environmental Microbiologv 36, 755-770.

TrolldeniER, G. (1973). The use of fluorescence microscopy for counting soil micro-organisms. Bulletin, Ecological Research Committee, Natural Science Research (Sweden) 17, 53-59.

VAN VEen, W. L. (1973). Bacteriology of activated sludge, in particular the filamentous bacteria. Antonie van Leeuwenhoek 39, 189-205.

Winfrey, M. R. \& Zeikus, J. G. (1979). Microbial methanogenesis and acetate metabolism in a meromictic lake. Applied and Environmental Microbiology 27, 213-221.

ZoBell, C. E. (1946). Marine Microbiology. Waltham, Mass.: Chronica Botanica. 